\title{
Xyloglucans from Hymenaea courbaril var. stilbocarpa seeds affect Arabidopsis thaliana seedling growth by enhancing lateral root development
}

\author{
ADRIANA TOURINHO SALAMONI I,5, MARIA-RITA SIERAKOWSKI ${ }^{2}$, \\ MONDHER EL JAZIRI ${ }^{3}$ and MARGUERITE QUOIRIN ${ }^{4}$
}

(received: April 24, 2008; accepted: September 16, 2010)

\begin{abstract}
Xyloglucans from Hymenaea courbaril var. stilbocarpa seeds affect Arabidopsis thaliana seedling growth by enhancing lateral root development). The effect of crude xyloglucan (XG) preparations from jatobá (Hymenaea courbaril var. stilbocarpa (Hayne) Y. T. Lee \& Langenh.) seeds on Arabidopsis thaliana (L.) Heynh. root system development was investigated. The XG extracts exerted a dual effect on root system development by slowing down root growth and improving lateral root formation. These observed morphological changes were not due to oligosaccharides that could be generated following hydrolysis of the XG polymers, since XG hydrolysate induced a drastic inhibition of the overall growth process of the Arabidopsis thaliana seedlings. Histochemical test of GUS gene expression assay performed on seven and 14-days-old transgenic Arabidopsis thaliana plants carrying the CycB1;1-GUS fusion indicated that the improvement of the lateral root development by jatobá XG extracts was not correlated with the expression of this cell cycle marker gene in the root system. A potential agricultural application of jatobá seeds XG extract is discussed.
\end{abstract}

Key words - jatobá, rhizogenesis, xyloglucan activity

RESUMO - (Xiloglucanas de sementes de Hymenaea courbaril var. stilbocarpa afetam o crescimento de plântulas de Arabidopsis thaliana aumentando o desenvolvimento de raízes laterais). O efeito de preparações de xiloglucanas (XG) de sementes de jatobá (Hymenaea courbaril var. stilbocarpa (Hayne) Y. T. Lee \& Langenh.) no desenvolvimento do sistema radicular de Arabidopsis thaliana (L.) Heynh. foi investigado. Os extratos de XG exerceram duplo efeito no sistema radicular, diminuindo o crescimento das raízes e aumentando a formação de raízes laterais. As alterações morfológicas observadas não foram causadas pelos oligossacarídeos que poderiam ter sido produzidos a partir da hidrólise do polímero de XG, já que o hidrolisado de XG induziu uma drástica inibição do processo de crescimento das plântulas de Arabidopsis thaliana. A análise histoquímica de expressão do gene GUS realizada com plantas de Arabidopsis thaliana transgênicas, com sete e 14 dias de idade, carregando a fusão CycB1;1-GUS, indicou que o melhor desenvolvimento das raízes laterais, com os extratos da XG de jatobá, não foi correlacionado com a expressão desse gene marcador do ciclo celular no sistema radicular. Uma potencial aplicação na agricultura dos extratos de XG de sementes de jatobá é discutida.

Palavras-chave - atividade da xiloglucana, jatobá, rizogênese

\section{Introduction}

One of the major cross-linking glycans of all primary cell walls of flowering plants is xyloglucan $(\mathrm{XG})$, which possesses a $\beta$ - $(1,4)$-glucan backbone to which $\alpha$-(1,6)-xylosyl residues are attached (Reid 1985,

1. Universidade Federal de Santa Maria, Cesnors, Departamento de Engenharia Florestal, Caixa Postal 54, 98400-000 Frederico Westphalen, RS, Brazil.

2. Universidade Federal do Paraná, Departamento de Química, Caixa Postal 19031, 81531-990 Curitiba, PR, Brazil.

3. Université Libre de Bruxelles, Faculté des Sciences, Laboratoire de Biotechnologie Végétale, CP 300, Rue des Professeurs Jeener et Brachet 12, 6041 Charleroi (Gosselies), Belgium.

4. Universidade Federal do Paraná, Departamento de Botânica, Caixa Postal 19081, 81531-990 Curitiba, PR, Brazil.

5. Correspondig author: adrisalamoni@smail.ufsm.br; adrisalamoni@hotmail.com
Hayashi 1989, Carpita \& McCann 2000, Lima et al. 2004). In germinating seeds of several plant species, the secondary cell wall of the cotyledons as well as of the endosperm contain little or no cellulose consisting mainly of XG that could have several functions such as mechanical dormancy, embryo protection and/or delivery of carbohydrates that are digested during germination (Carpita \& McCann 2000).

Loosening and rearrangement of the cell wall during plant cell growth and differentiation requires cleavage and molecular grafting of XG chains, a process mediated by several enzymes among which xyloglucan endotransglucosylase (XET) is shown to play a critical role (Rose et al. 2002). In the root system of diverse vascular plants, high XET activity was localized in the epidermic cell wall of the elongation zone and in trichoblasts in the differentiation zone (Vissenberg et 
al. 2003). On the other hand, it has been demonstrated that the integration of XG mediated by the action of wall-bound XET suppressed cell elongation in pea stem segments by affecting microtubule orientation (Takeda $e t$ al. 2002), supporting the significance of $X G$ integration in controlling the cell growth process. In contrast, these authors showed that the integration of XG-derived oligosaccharides (XGOs) accelerates cell elongation. Some of the XG-derived oligomers with particular structural features (such as reduced forms of XXLG or XXXG) have been shown to act as signalling molecules, suggesting the occurrence of specific recognition systems for these oligosaccharides in plants (Vargas-Rechia et al. 1998).

XG extracted from Hymenaea courbaril var. stilbocarpa (Hayne) Y. T. Lee \& Langenh. (jatobá) seeds, a Brazilian native tree, was found to be useful as a partial substitute for agar as a gelling agent in culture media for in vitro plant micropropagation (LimaNishimura et al. 2003). These authors also showed that a mixture of $0.4 \%$ agar and $0.2 \%$ jatobá $\mathrm{XG}$ resulted in an improved multiplication rate, reduced callus formation and shoot hyperhydricity and particularly a better rooting performance. In the absence of auxin, the rooting rate of Marubakaido apple microcuttings reached $70.8 \%$ on a medium solidified with a mixture of agar and $\mathrm{XG}$, instead of $6.7 \%$ on the agar control medium.

In the present study Arabidopsis thaliana (L.) Heynh. was used as a model plant in order to assess the effect of jatobá seeds XG on root system development.

\section{Material and methods}

Xyloglucan extracts - Seeds of Hymenaea courbaril (Fabaceae) were collected at two different locations in Brazil: Cuiabá (south of Mato Grosso State) and Sinop (centre of Mato Grosso State). These seeds were weighted and the tegument was removed manually after seed treatment with boiled water. The polysaccharide was extracted from the seeds with water in a blender with controlled velocity. The viscous extracts obtained were centrifuged at $7000 \mathrm{rpm}$ for 40 minutes and the supernatant was treated with sodium chloride $0.1 \mathrm{M}$ and 1-2 volumes of ethanol. The precipitated polysaccharide was collected and dried at $25^{\circ} \mathrm{C}$, giving XGC (xyloglucan extracted from jatobá seeds from Cuiabá) and XGS (xyloglucan extracted from jatobá seeds from Sinop). For the purification process samples of XGC in aqueous solution were passed through Millipore filter membranes with pore sizes of 3 and $0.8 \mu \mathrm{m}$, this product was called XGCP and through membranes with pore sizes of $3,0.8$ and $0.22 \mu \mathrm{m}$, this product was called XGCPP. After filtrations the polysaccharide was precipitated with 1-2 volumes of ethanol.
Xyloglucan analysis - Total XGC carbohydrate content was determined by the phenol-sulphuric method (Dubois et al. 1956) and the protein content of samples of XGC, XGCP and XGCPP was determined by the method of Hartree (1972). Monosaccharide contents of XGC were determined by complete acid hydrolysis with $2 \mathrm{M}$ trifluoroacetic acid (TFA) at $100^{\circ} \mathrm{C}$ for 8 hours (Adams 1965). The products of hydrolysis were reduced with sodium borohydride $\left(\mathrm{NaBH}_{4}\right)$ and acetylated with pyridine-acetic anhydride (Wolfrom \& Thompson 1963). The resulting alditol acetates were analysed by GLC using an HP model 5890-2, with a DB-225 cappilary column at $220^{\circ} \mathrm{C}$, a flame ionization detector at $250{ }^{\circ} \mathrm{C}$ and nitrogen as carrier gas. Freitas et al. (2005) assayed the XGS by the same method.

$\mathrm{XGC}$ hydrolysis - XGC was hydrolysed with a cellulase from Trichoderma reesei (Celluclast 1.5L) (Novo Nordisk ${ }^{\circledR}$, Bioindustrial do Brasil). The enzymatic solution was prepared with $144 \mathrm{mg}$ cellulase $\left(3.36 \mathrm{EGU} \mathrm{mL}^{-1}\right)$ dissolved in $0.5 \mathrm{M}$ acetate buffer ( $\mathrm{pH}$ 5.0). Cellulase solution and XGC were mixed (144 mg cellulase for $150 \mathrm{mg} \mathrm{XGC)}$ at $64.5^{\circ} \mathrm{C}$ for 45 minutes. After hydrolysis, enzymatic inactivation was carried out for $20 \mathrm{~min}$ at $100^{\circ} \mathrm{C}$. The product of this hydrolysis was freezed, lyophilized and called XGCH.

Transgenic Arabidopsis thaliana (C24) plants - Transgenic Arabidopsis thaliana (C24) plants containing the Arath;CycB1;1-GUS fusion (Ferreira et al. 1994) were grown under axenic conditions. Surface disinfected seeds were incubated for germination in Murashige \& Skoog (1962) semi-solid culture medium (MS) supplemented with $0.029 \mathrm{M}$ sucrose. After addition of XGs or XGCH and 2,4-dichlorophenoxyacetic acid (2,4-D), the media were autoclaved for 20 minutes at $120^{\circ} \mathrm{C}$ and $1.5 \mathrm{~atm}$. The seeds were incubated at $6{ }^{\circ} \mathrm{C}$ overnight and then maintained at $26 \pm 2{ }^{\circ} \mathrm{C}$ under fluorescent light (Philips "white comfort") providing a photon flux density of $40 \mu \mathrm{mol} \mathrm{m}^{-2} \mathrm{~s}^{-1}$, and photoperiod of 16 hours. Four-day-old seedlings were used to test the effect of XGs and XGCH. To calculate the XGC and XGS molar concentrations, the molecular masses, respectively, of $2.2 \times 10^{6}$ and $1.05 \times 10^{6} \mathrm{~g} \mathrm{~mol}^{-1}$, as determined by Freitas et al. (2005), were used. To calculate the XGCH molar concentration the molar mass of the octasaccharide that appears in highest amount in the polysaccharide structure of jatobá seeds, the oligosaccharide XXLG was used.

Each treatment formulated consisted of two replicates with five seedlings each. The experiment was repeated twice. After seven and 14 days of treatment, the root length, the number of lateral roots and the hypocotyl length were scored. The histochemical $\beta$-glucuronidase (GUS) assays were performed on seven and 14-day-old seedlings as described by Jefferson et al. (1987). The data were analyzed statistically by one-way analysis of variance. The mean values were compared by Tukey's multiple range tests using the Michigan State University statistical package. 


\section{Results}

Xyloglucan composition - The total carbohydrate content of XGC was $73.5 \%(\mathrm{w} / \mathrm{w})$. The protein composition of the samples $(\mathrm{w} / \mathrm{w})$ was $8.7 \%$ for XGC, $5.6 \%$ for XGCP and $5.6 \%$ for XGCPP. The monosaccharide composition of the XGC, as alditol acetate derivative, was glucose, xylose and galactose, in the molar ratio of $3: 2.6: 1$, respectively. The results obtained by Freitas et al. (2005) showed that the protein and carbohydrate levels are only slightly different. Total carbohydrate content of XGC was $86 \%$ and XGS was $85 \%$. The protein content of the samples was $2.9 \%$ for XGC and $2.2 \%$ for XGS.

Arabidopsis thaliana seedling growth - After seven days of culture in the presence of $500 \mathrm{nM} \mathrm{XGC}$ and $1200 \mathrm{nM}$ XGS extracts, the root length was reduced in comparison to the MS control cultures (figure 1A). This effect was greater after 14 days of culture, particularly for seedlings grown in the presence of XGS extract, which showed a significant root growth reduction even at a 10 -fold dilution $(120 \mathrm{nM})$. Interestingly, the number of lateral roots increased in seedlings cultured for 14 days in both jatobá XG extracts (figure 1C). Among the different treatments, the maximum number of lateral roots was observed after 14 days of culture in the medium supplemented with 1.2 or $120 \mathrm{nM} \mathrm{XGS.}$ Finally, hypocotyl length was slightly affected by the XG extracts, in the presence of $500 \mathrm{nM}$ XGC after seven days of culture and in $1200 \mathrm{nM}$ XGS after seven and 14 days of culture (figure 1B). In fact, in A. thaliana seedlings cultured in the presence of $0.1 \mu \mathrm{M} 2,4-\mathrm{D}$, root length was reduced and number of lateral roots was increased, when compared to control auxin-free cultures (figure 3).

To better characterize the physiological activity observed, the effect of cellulase hydrolysed XGC (XGCH) was investigated. As shown in figure 2, the overall growth parameters of the $A$. thaliana seedlings were affected by the XGCH. Root (figure 2A) and hypocotyl (figure 2B) growth were significantly reduced in seedlings cultured for 14 days in the presence of $250 \mathrm{nM} \mathrm{XGCH}$. Moreover, these seedlings did not form lateral roots (figure 2C). When seven-day-old seedlings were transferred to $\mathrm{XGCH}$-free medium, seedling growth resumed, indicating a reversible growth-inhibiting effect. However, growth of 14-day-old treated seedlings did not resume on XGCH-free medium, indicating a toxic effect of $\mathrm{XGCH}$ after prolonged time of incubation (Salamoni 2004).

Change of expression in transgenic Arabidopsis thaliana seedlings - The effects of jatobá XG on the growth of A. thaliana seedlings were monitored by following the
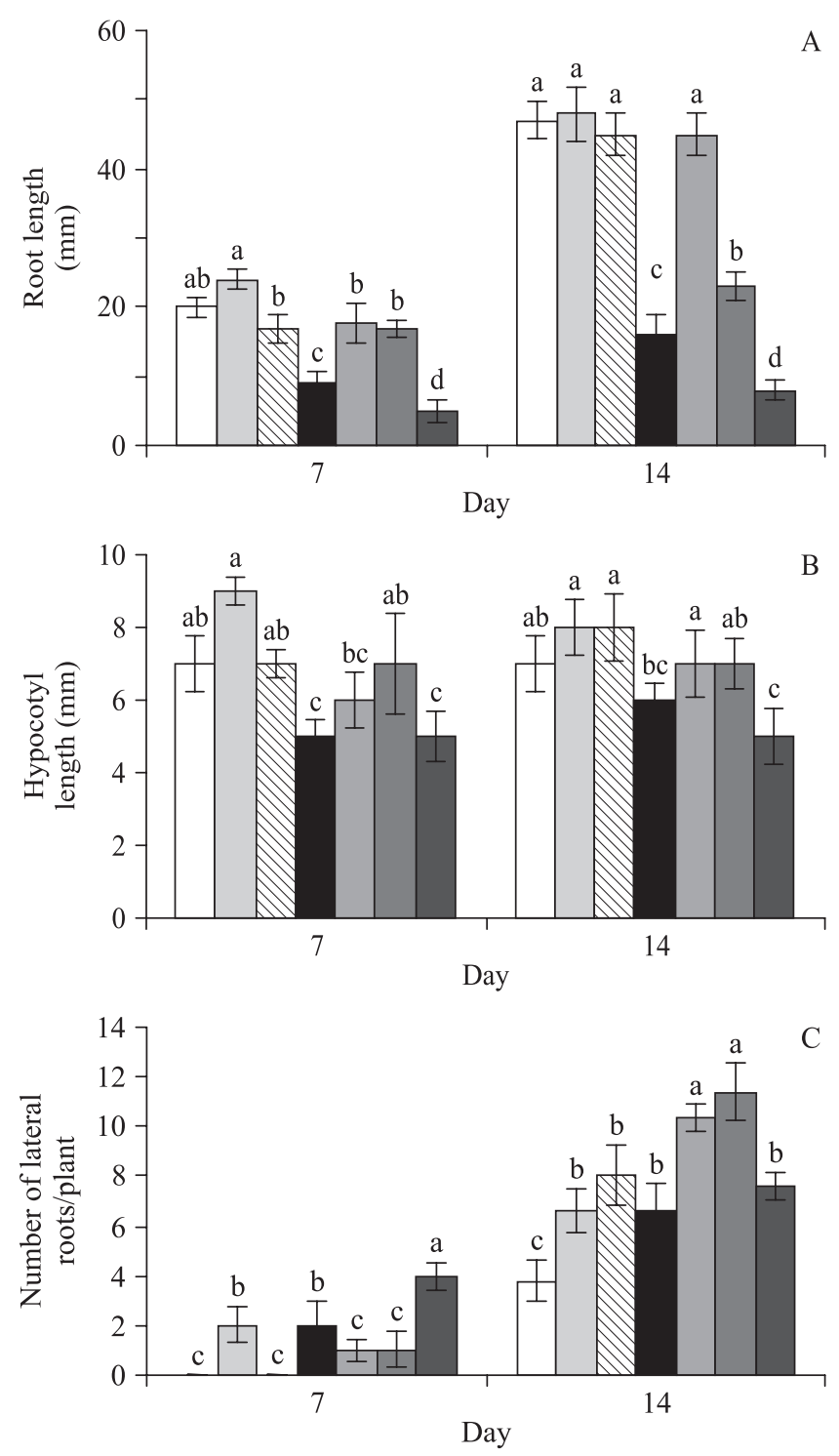

Figure 1. Effect of two xyloglucans (XGC and XGS) on root length (A), hypocotyl length (B) and number of lateral roots/plant (C) of A. thaliana seedlings. Each value represents the mean $( \pm$ SD) of ten plantlets. $(\square=\mathrm{MS} ; \square=\mathrm{XGC} 0.5 \mathrm{nM}$; $\mathbb{W}=$ XGC $50 \mathrm{nM} ; \boldsymbol{\square}=$ XGC $500 \mathrm{nM} ; \square=$ XGS $1.2 \mathrm{nM}$; $\square=$ XGS $120 \mathrm{nM}$ - = XGS $1200 \mathrm{nM}$ ).

changes in expression of $\mathrm{CycB} 1 ; 1$ in transgenic plants which carry the $\mathrm{CycB} 1 ; 1$ promoter-GUS fusion. The expression profile of Arath; $\mathrm{CycB} 1 ; 1$ is restricted to $\mathrm{G} 2$ and $\mathrm{M}$ phases and to actively dividing cells (Ferreira et al. 1994, Shaul et al. 1996). Transgenic A. thaliana seedlings were cultured either in a control MS medium or in the same basal medium supplemented with 500, 1200 and $250 \mathrm{nM}$ of XGC, XGS and XGCH, respectively. The combined effect of XGs and 2,4-D $(0.1 \mu \mathrm{M})$ was also investigated (figure 3). In an auxin-free medium, GUS expression was not detected within root system of seven 

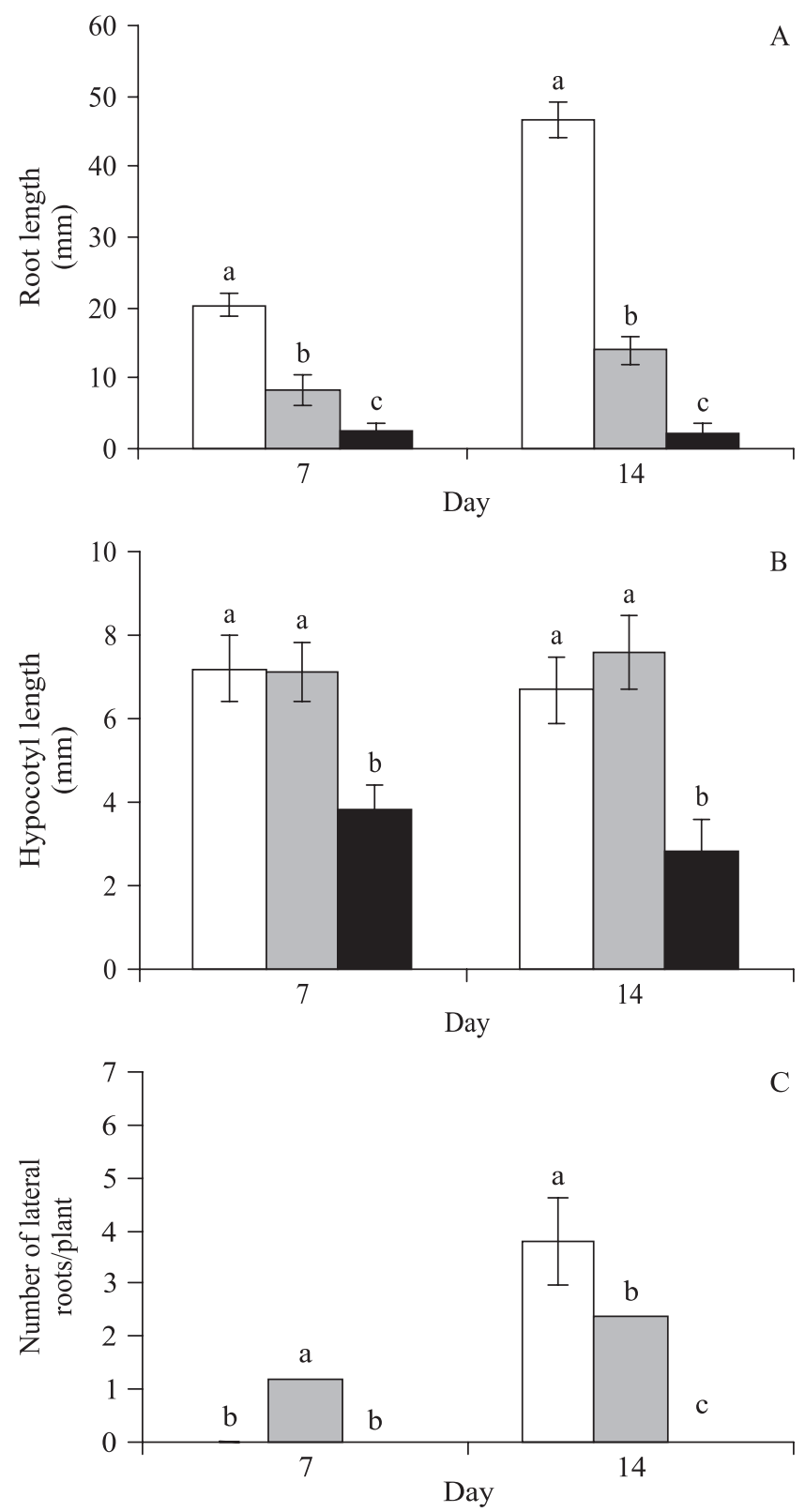

Figure 2. Effect of XGCH on root length (A), hypocotyl length (B) and number of lateral roots/plant (C) of $A$. thaliana seedlings. Each value represents the mean $( \pm \mathrm{SD})$ of ten plantlets. ( $\square=\mathrm{MS} ; \square=\mathrm{XGCH} 25 \mathrm{nM} ;=\mathrm{XGCH}$ $250 \mathrm{nM})$.

and 14-day-old seedlings independently from XGs or $\mathrm{XGCH}$ supply (figure 3A-H). In 2,4-D supplemented medium, GUS expression within the root system was localized in lateral root meristems (figure 3I). These new root meristems further developed into lateral roots and GUS expression was no longer detected (figure 3J). However, when crude XG extracts (XGC or XGS) were combined with 2,4-D, GUS expression within the root system was maintained throughout the culture period till day 14 (figure 3K-N). Moreover, these induced root meristems did not elongate further, resulting in a short lateral root system (figure $3 \mathrm{~L}$ and $\mathrm{N}$ ), whereas lateral roots were well developed in XG supplemented medium only (figure 3D and F). These data suggest a synergic effect between $\mathrm{XG}$ and auxin. XGCH inhibited both main root growth and lateral root formation independently from the 2,4-D supply. Within the aerial part of the plantlets cultured in the presence of XGS, GUS expression was localised in the cotyledons and in the 2-3 first leaves (figure $3 \mathrm{E}, \mathrm{F}, \mathrm{M}$ and $\mathrm{N}$ ). This expression was much reduced or absent in plants grown on XGC media (figure $3 \mathrm{C}, \mathrm{D}, \mathrm{K}$ and $\mathrm{L}$ ).

\section{Discussion}

In an attempt to improve the performance of in vitro micropropagated plants, it has been found that in the absence of auxin, a mixture of agar-jatobá XG as gelling agent for culture media enhances the multiplication rate, reduces the occurrence of hyperhydric shoots and improves rooting of adventitious shoots (LimaNishimura et al. 2003). The present study was conducted in order to better characterize the effect of crude jatobá XG extract and XG hydrolysate on root system development.

As the difference between XGC and XGCP protein composition was low (8.7 to $5.6 \%$ ), it was not necessary to purify the extract through Millipore filter membranes. Therefore, the crude XGCs characterized as glycopeptides were used.

We were able to demonstrate that crude jatobá XG extracts (XGC and XGS) can act by inhibiting root growth and improving lateral root formation. This dual physiological effect is dose-dependent (figure 1) and shows auxin-like effect. Furthermore, jatobá XG hydrolysate reversibly inhibits the root system development. The auxin-like effect of jatobá XGs on A. thaliana root development (figure 3) may be due to the presence of active oligosaccharides released by hydrolysis of XG following metabolization by the plant enzymes xyloglucan endotransglucosylases, glucanases and xylosidases. However, this effect may also be due to the hydrolysis of oligosaccharides into the monosaccharides glucose, xylose and galactose.

Rolland \& Sheen (2005) indicated the role of sugars as signalling molecules in plants. The flexible and reversible responses to both low and high glucose signals in plant growth promotion and inhibition, respectively, depend on cell type, developmental state, multiple nutrients status and environmental conditions. According to Léon \& Sheen (2003) the transcript levels 

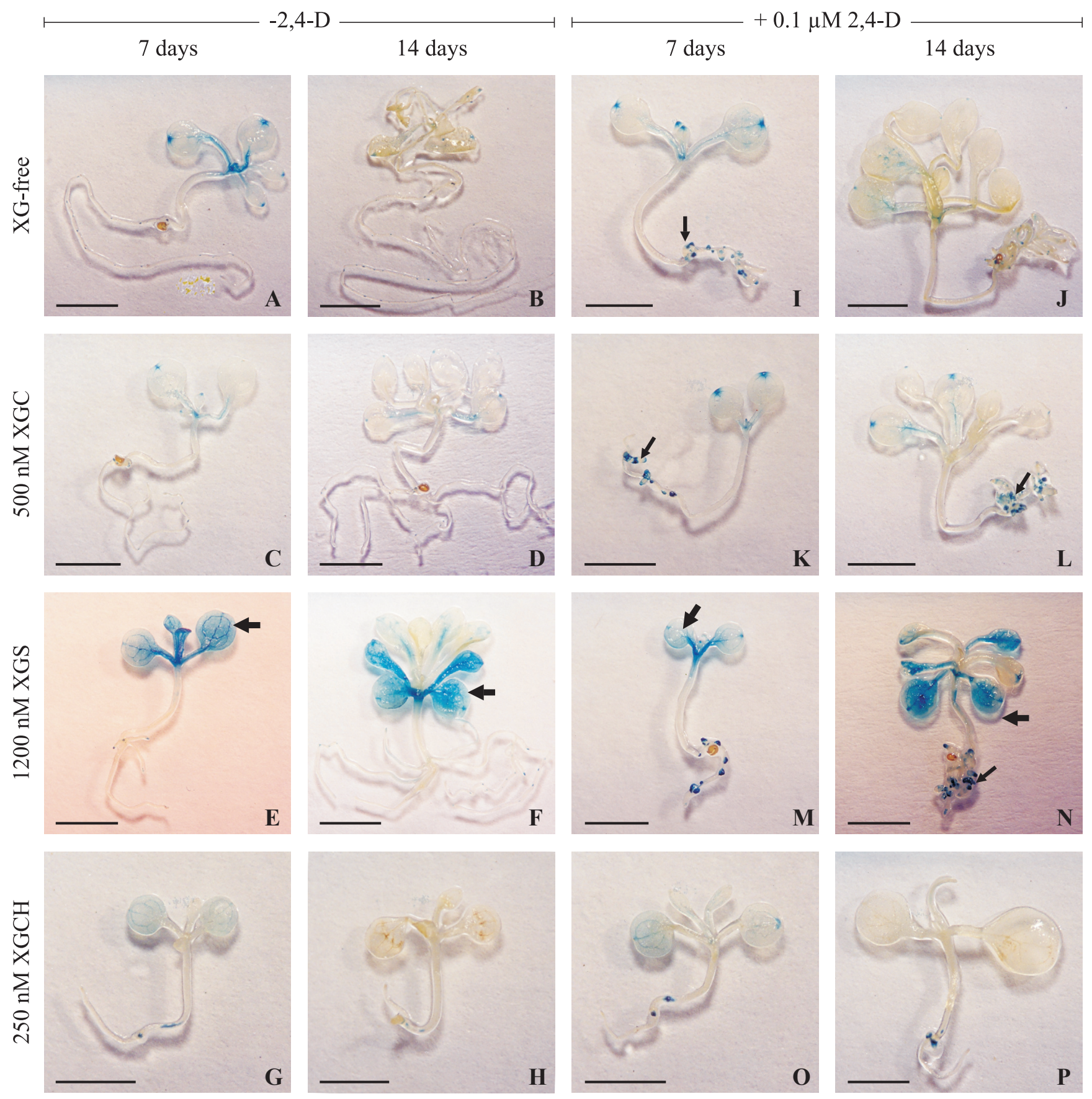

Figure 3 (A-P). GUS expression pattern and seedling phenotypes of 7- and 14-day-old A. thaliana seedlings cultured in XG-free medium or in medium supplemented with 500, 1200 or $250 \mathrm{nM}$ of XGC, XGS or XGCH, respectively. The experiment was performed in auxin-free medium or in the presence of $0.1 \mu \mathrm{M}$ of 2,4-D. Narrow arrows show the lateral root meristem. Thick arrows show the GUS expression in the aerial part of the plantlets. Bar $=5 \mathrm{~mm}$.

of several abscisic acid (ABA) biosynthesis genes are raised by glucose, suggesting a direct, specific glucose modulation of ABA biosynthesis genes and ABA accumulation. The effect of excess glucose during the seedling establishment stage results in an arrest of seedling growth and differentiation that seems to be mediated partly by the increase in ABA biosynthesis and by the activation of same ABA signaling genes. It will be interesting to carry out more-detailed analyses of the expression patterns of other ABA biosynthesis genes and their responses to sugars as well as their roles in sugar signaling. While sucrose is the most important transport sugar in plants, most regulatory effects can be ascribed to glucose (Ramon et al. 2008). 
The observed effects cannot be attributed to a possible modification of the physical properties of the solid medium following addition of XG extract, since rheologic measurements indicated that the consistency of these media was identical to that of medium containing agar only (Lima-Nishimura et al. 2003). Moreover, experiments conducted with $A$. thaliana plantlets cultured in liquid medium supplemented with either XGs or $\mathrm{XGCH}$, confirmed the effects on rooting that we observed in solid medium (Salamoni 2004). Differences in GUS expression in A. thaliana seedlings grown in medium supplemented with XGC or XGS indicated a difference in the effect of both jatobá XG extracts, probably related with their fine chemical composition which may differ in function of their geographical origin.

Freitas et al. (2005) related differences in the relative proportion of XXXG, XXLG, XLLG + XXXXG and XXLXG oligosaccharides between both xyloglucan polymers. The concentration of the mixture XLLG+XXXXG was $30.3 \%$ for XGC and $25.8 \%$ for XGS. So, as firstly observed by Buckeridge et al. (1997) for jatobá from São Paulo, the XGC probably presents more oligosaccharides of the new series. Moreover, there was little difference in the total content of carbohydrates and proteins for jatobá seeds collected in different regions of Brazil.

Mechanical changes underlying primary cell wall re-modelling and consequently the growth process has been shown to be mediated by the XETs (Chanliaud et al. 2004). Beside their function as a catalyst of cell wall loosening, XETs are responsible for the incorporation of new XG molecules synthesized during plant growth (Sulová et al. 2003). The suppression of root elongation observed in the presence of $500 \mathrm{nM} \mathrm{XGC} \mathrm{(figure} \mathrm{1A)}$ could be explained by the integration of XG into the cell wall by the plant XET activity. A similar effect has been described for pea stem segments where incorporation of XG suppressed cell wall extension and, consequently, cell elongation (Takeda et al. 2002). These authors showed that integration of XG into the primary cell wall induces rearrangement of cortical microtubules from a transverse to a longitudinal position resulting in the suppression of cell elongation.

Seedlings cultured for 14 days in the presence of XG extracts (figure 3D and F) or 2,4-D (figure 3J) developed a similar number of lateral roots but for the latter the root length was reduced, indicating a different mode of action between $\mathrm{XG}$ and auxin at least during the root elongation process. Further molecular analyses based on differential gene expression between XG and 2,4-D treated plants will certainly contribute to the identification of molecular markers associated with root meristem formation and/or root elongation.

It was also shown that morphological changes induced on $A$. thaliana root system cultured in the presence of XG were not due to oligosaccharides that could be generated following hydrolysis of the $\mathrm{XG}$ polymers because $\mathrm{XGCH}$ induced a drastic inhibition effect on the overall growth process of the $A$. thaliana seedlings, indicating a possible action of the $\mathrm{XGCH}$ component(s) on fundamental growth processes in plant. Nevertheless, up to 7 days post-treatment, this inhibiting effect is reversible, as seedling growth resumed after transfer into an XGCH-free medium. New studies need to be carried out with isolated XGOs in order to understand the role of each of them on root growth and lateral root formation.

From the results presented in this study, a potential agricultural and/or horticultural application may be considered for jatobá XGs. Root system implementation is a crucial developmental process especially during the first stage of plant growth. A well-developed root system results in an increased root surface allowing efficient nutrient assimilation by the plant either directly from the soil or through rhizosphere-associated plant growth promoting rhizobacteria and fungi. Seeds pre-treated with jatobá XG extract may therefore represent an interesting approach for the improvement of plant growth efficiency, by providing seedlings with a well-developed root system. Moreover, jatobá XG can be used as a substitute for auxin during the rooting stage of in vitro micropropagated plantlets.

Acknowledgments - The authors are grateful to Professor Dirk Inzé from Plant System Biology Department (VIB-Gent University, Belgium) for providing the $A$. thaliana transgenic seeds, to Novo Nordisk ${ }^{\circledR}$ (Bioindustrial do Brasil) for cellulase donation and to Embrapa (Brazil) for $H$. courbaril seeds. The authors thank $\mathrm{CNPq}$ and Capes for financial support.

\section{References}

ADAMS, G.A. 1965. Acid hydrolysis of weak linkages. In Methods in carbohydrate chemistry. (R.L. Whistler, J.N. BeMiller \& M.L. Wolfrom, eds.). Academic Press, New York, v.5, p.285-287.

BUCKERIDGE, M.S., CROMBIE, H.J., MENDES, C.J.M., REID, J.S.G., GIDLEY, M.J. \& VIEIRA, C.J. 1997. A new family of xyloglucan oligosaccharides from cotyledons of Hymenaea courbaril: structure determination of the oligosaccharide XXXXG by enzymatic sequencing \& NMR. Carbohydrate Research 303:233-237. 
CARPITA, N. \& MCCANN, M. 2000. The cell wall. In Biochemistry and molecular biology of plants (B.B. Buchanan, W. Gruissem \& R.L. Jones, eds.). American Society of Plant Physiologists, Rockville, p.52-109.

CHANLIAUD, E., DE SILVA, J., STRONGITHARM, B., JERONIMIDIS, G. \& GIDLEY, M.J. 2004. Mechanical effects of plant cell wall enzymes on cellulose/xyloglucan composites. Plant Journal 38:27-37.

DUBOIS, M., GILLES, K.A., HAMILTON, J.K., REBERS, P.A. \& SMITH, F. 1956. Colorimetric method for determination of sugars and related substances. Analytical Chemistry 28:350-356.

FERREIRA, P.C.G., HEMERLY, A.S., ENGLER, J.A., VAN MONTAGU, M.V., ENGLER, G. \& INZÉ, D. 1994. Developmental expression of the Arabidopsis cyclin gene cyc1At. Plant Cell 6:1763-1774.

FREITAS, R.A., MARTIN, S., SANTOS, G.L., VALENGA, F., BUCKERIDGE, M.S., REICHER, F. \& SIERAKOWSKI, M.-R. 2005. Physico-chemical properties of seed xyloglucans from different sources. Carbohydrate Polymers 60:507-514.

HARTREE, E.F. 1972. Determination of protein: a modification of the Lowry method that gives a linear photometric response. Analytical Biochemistry 28:422-427.

HAYASHI, T. 1989. Xyloglucans in the primary cell wall. Annual Review of Plant Physiology and Plant Molecular Biology 40:139-168.

JEFFERSON, R.A., KAVANAGH, T.A. \& BEVAN, M.W. 1987. GUS fusions: B-Glucuronidase as a sensitive and versatile gene marker in higher plants. EMBO Journal 6:3901-3907.

LÉON, P. \& SHEEN, J. 2003. Sugar and hormone connections. Trends in Plant Science 8:110-116.

LIMA, D.U., LOH, W. \& BUCKERIDGE, M.S. 2004. Xyloglucan-cellulose interaction depends on the sidechains and molecular weight of xyloglucan. Plant Physiology and Biochemistry 42:389-394.

LIMA-NISHIMURA, N., QUOIRIN, M., NADDAF, Y.G., WILHELM, H.M., RIBAS, L.L.F. \& SIERAKOWSKI, M.-R. 2003. A xyloglucan from seeds of the native Brazilian species Hymenaea courbaril for micropropagation of Marubakaido and Jonagored apples. Plant Cell Reports 21:402-407.

MURASHIGE, T. \& SKOOG, F. 1962. A revised medium for rapid growth and bioassay with tobacco tissue cultures. Physiologia Plantarum 15:473-497.
RAMON, M., ROLLAND, F. \& SHEEN, J. 2008. The Arabidopsis book: sugar sensing and signalling. American Society of Plant Biologists, Rockville.

REID, J.S.G. 1985. Cell wall storage carbohydrates in seeds Biochemistry of the seed "gums" and "hemicelluloses". Advances in Botanical Research 11:125-155.

ROLLAND, F. \& SHEEN, J. 2005. Sugar sensing and signalling networks in plants. Biochemical Society Transactions 33:269-271.

ROSE, J.K., BRAAM, J., FRY, S.C. \& NISHITANI, K. 2002. The XTH family of enzymes involved in xyloglucan endotransglucosylation and endohydrolysis: current perspectives and a new unifying nomenclature. Plant Cell Physiology 43:1421-1435.

SALAMONI, A.T. 2004. Obtenção, caracterização e efeitos de xiloglucanas e derivados, de sementes de jatobá na cultura de tecidos vegetais. Tese de doutorado, Universidade Federal do Paraná, Curitiba.

SHAUL, O., MIRONOV, V., BURSSENS, S., VAN MONTAGU, M. \& INZÉ, D. 1996. Two Arabidopsis cyclin promoters mediate distinctive transcriptional oscillation in synchronized tobacco BY-2 cells. Proceedings of the National Academy of Sciences 93:4868-4872.

SULOVÁ, Z., BARAN, R. \& FARKAS, V. 2003. Divergent modes of action on xyloglucan of two isoenzymes of xyloglucan endo-transglycosylase from Tropaeolum majus. Plant Physiology and Biochemistry 41:431-437.

TAKEDA, T., FURUTA, Y., AWANO, T., MIZUNO, K., MITSUISHI, Y. \& HAYASHI, T. 2002. Suppression and acceleration of cell elongation by integration of xyloglucans in pea stem segments. Proceedings of the National Academy of Sciences 99:9055-9060.

VARGAS-RECHIA, C., REICHER, F., SIERAKOWSKI, M.-R., HEYRAUD, A., DRIGUEZ, H. \& LIÉNART, Y. 1998. Xyloglucan octasaccharide XXLGol derived from the seeds of Hymenaea courbaril acts as a signalling molecule. Plant Physiology 16:1013-1021.

VISSENBERG, K., VAN SANDT, V., FRY, S.C. \& VERBELEN,J.P.2003.Xyloglucanendotransglucosylase action is high in the root elongation zone and in the trichoblasts of all vascular plants from Selaginella to Zea mays. Journal of Experimental Botany 54:335-344.

WOLFROM, M.L. \& THOMPSON, A. 1963. Acetylation methods. In Methods in carbohydrate chemistry. (R.L. Whistler, M.L. Wolfrom \& J.N. BeMiller, eds.). Academic Press, New York, v.2, p.211-215. 
